\title{
A TYPOLOGY OF SHRINKING CITIES: THE SOCIAL AND ECONOMIC DYNAMIC OF ROMANIAN URBAN NETWORK 2010-2020
}

\author{
NORBERT PETROVICI'1, VLAD BEJINARIU ${ }^{2}$
}

\begin{abstract}
The aim of the paper is to open the issue of multiple shrinkage trajectories in a context of extended urbanisation (Keil 2018) by delineating the different trajectories of Romanian cities. We employed principal component analysis to allow for a multi-criterial classification of Romanian cities based on k-means cluster analysis. Beyond the dominant representation of shrinkage as a process that is mainly correlated with population loss and economic decline, this paper calls for bridging together distinct dimensions which have been either under-studied, such as the aspect of human development, or studied separately across the existing literature, such as governance of shrinkage and economic growth. Therefore, the typology developed here accounts for understanding the process of shrinkage as a complex process, having multiple causes, which determine peculiar trajectories. The outcome confirms the existence of distinct and highly localised shrinkage identities (Martinez-Fernandez, Audirac, etal. 2012). We show that regrowth is not strictly related to the urban core, but it has more to do with a process of complexification of the landscape and social relations existing at the periphery of the city. Shrinking core cities coexists with growing peri-urban areas.
\end{abstract}

Keywords: shrinking cities, extended urbanisation, peri-urbanisation, growth poles.

1 Associate Professor at Babeș-Bolyai University; norbert.petrovici@ubbcluj.ro

2 MA Student at Babeș-Bolyai University; vlad.bejinariu@stud.ubbcluj.ro

3 FUNDING. The research developed in this chapter was supported by the World Bank, a report delivered under the provisions of the Reimbursable Advisory Services Agreement on the Romania Urban Policy (P171176) coordinated by the Ministry for Development, Public Works, and Administration of Romania. The research has been prepared under the guidance and supervision of Yondela Tembakazi Silimela, Carli Bunding-Venter and Marcel Ionescu-Heroiu. The text does not reflect the World Bank position nor that of the Ministry for Development, Public Works, and Administration. The paper is an independent original analysis that was not the object of the services agreement.

ACKNOWLEDGEMENTS. The authors would like to thank the kind input of Yondela Tembakazi Silimela, astute observations of Carli Bunding-Venter, the expert comments and guidance of Marcel Ionescu-Heroiu, and the generous exchange of ideas with Alexandra Beatrice-Nae. The authors are grateful for the language editing done by Alexandra Petrovici. 


\section{Introduction}

The debate over the process of urban shrinkage continues to be relevant in the field of urban studies, gaining momentum in the decade following the 2008 financial crisis (Audirac 2018). While the phenomenon of urban depopulation became of concern in the 1990s with the demises of socialism in Eastern Europe (Mykhnenko and Turok 2008), a growing academic interest re emerged in the post-crisis era, which left a significant mark on peripheral European cities. The last decade witnesses a resurgent interest in case studies focusing on cities with more than 200,000 inhabitants (Haase et al. 2021). When studying the process of shrinkage there is a need to be place and time specific (Haase et al. 2014, 2016). Shrinkage identities (Martinez-Fernandez, Audirac, et al. 2012) emerged as a conceptual tool to account exactly for the multi-dimensional causes at interplay in localised ongoing processes of demographic, economic and social contraction (Rink et al. 2014). However, as Wolff et al. (2017) astutely points out, engaging mainly with larger cities, leaves out a considerable number of urban settlements with their specific shrinking trajectories. The aim of this paper is to develop a typology which includes the whole urban spectrum from Romania, and accounts for place and time trajectory. This is of great importance as $36,7 \%$ of Romania's cities have a population below 10.000 inhabitants, and $35,1 \%$ have a population between 10.000 and 25.000 inhabitants (Rotariu, Dumănescu, and Hărăguș 2017). In fact, the urban distribution of population in Romania is identical with the larger European one (Wolff and Wiechmann 2018), transforming this urban network into a laboratory to develop shrinkage typologies, without losing sight of local specificities.

Eastern Europe became the focus of research on urban shrinkage in the 1990s, but the focus of the literature was on post-socialist transformation. The process of urban contraction is generally analysed from a rigorous demographic perspective to address depopulation and recent demographic changes (Bănică, Istrate, and Muntele 2017; Eva, Cehan, and Lazăr 2021), or from the broader framework of deindustrialization (Popescu 2014). Moreover, the current literature follows the larger European academic trend of case studies on shrinking identities and trajectories, through in depth studies of Timișoara (Lucheș, Nadolu, and Dincă 2011; Rink et al. 2014), Bucharest (Ianoş et al. 2016) or the mining cities of Valea Jiului (Constantinescu 2012). However, recent scholarship emphasised upon the multi-causality of shrinkage (Haase et al. 2016; Martinez-Fernandez, Audirac, et al. 2012; Wolff and Wiechmann 2018) and how localities respond to it (Pallagst et al. 2021). This paper aims to move away from the generic postsocialist framework and deindustrialization to build a typology of urban shrinkage in Romania by including variables that encompass the multiple dimensions of the process: demographic, floor space, economic, human development, urban governance, city expenditure and the environmental situation. 
Moreover, the current paper discusses the process of shrinkage in its specific varieties and aims for a non-linear understanding of the phenomenon (Wolff et al. 2017). Despite population loss emerging as a general trend for urban settlements in Europe, more recently a reverse trend of regrowth has become evident in certain cities (Kabisch, Haase, and Haase 2010). The existing literature regarding regrowth follows two distinct paths. The first one is engaging with the idea of reurbanization and argues for the increase of population density within the city (Broitman and Koomen 2020; Kabisch et al. 2010; Wolff et al. 2017), while examining the impact on the built-up area and green spaces (Wolff et al. 2017). The second narrative distances itself from the argument for densification and the concept of reurbanization, by examining the current dynamic from the framework of extended urbanisation. Keil (2018) argues that what we witness is a new process, one which differs qualitatively from reurbanisation. The focal point in his analysis is that of suburbanism, which is ignored in the previous category as it is seen rather as a driving force for population loss. Keil (2018) considers the contemporary practices of urban peripheralisation to be structurally different and more complex than what are traditionally thought of as suburbs, naming the phenomenon post-suburbanism. To be more precise, the problem of regrowth is not one strictly related to the urban core, but it has more to do with a process of complexification of the landscape and social relations existing at the periphery of the city. Starting from this point of tension between the two bodies of literature, the present paper reflects on the ongoing dynamic of population regrowth and certain cities of Romania. Special attention is paid in this regard to peri-urban localities and their transformation in the last decade, as they are specific local examples, closely related to what Keil envisaged as post-suburbia.

The paper is organised in six sections. First, we discuss the literature on shrinking cities in the context of extended urbanisation. Second, we present our data, and the main indexes we use in this analysis. Third, we lay down the methodological strategy of the paper. The results are presented in three separate subsections: one that deals with the index construction based on principal component analysis, one that outlines the groups of cities based on a cluster analysis, and one that further divides the cities into subgroups based on a new iteration of the cluster analysis. The final section is a conclusion that summarises the findings.

\section{Post-shrinkage in the context of extended urbanisation}

While the literature on the process of urban shrinkage has been mainly case-study oriented (Haase et al. 2021), there is some recent scholarship which examines the existing body of knowledge with the scope of developing an 
integrative conceptual apparatus (Bernt 2016; Haase et al. 2014). Hassel et al. (2014) observe here a tension between existing macro-theoretical debates and their empirical base. As Bernt (2016) argues, the existing literature tends to be either focused on single-cases - for example former mining cities (Constantinescu 2012; Martinez-Fernandez, Wu, et al. 2012) or larger cites -, or it tends to develop analyses based upon a single variable, for example population loss. The outcome is a simplistic understanding of urban shrinkage as a linear phenomenon, being opposed to urban growth (Haase et al. 2021). While typologies of shrinkage have been developed (Eva, Cehan, and Lazăr 2021; Wiechmann and Wolff 2013; Wolff and Wiechmann 2018), they rarely escape the tension between case studies or single variable use. That is why Hassel et al. (2014) calls for a multidimensional investigation that can accommodate the multiplicities of path specific urban shrinkages. Our paper responds to this call and our aim is to develop a multicriterial typology of the Romanian cities. Such an endeavour has the potential to generate a non-linear account of the shrinking processes and it could potentially dissolve the apparent contradiction between shrinkage and growth.

As Haase et al. (2014) observes, the process of shrinkage, far from being new, has been documented extensively by different branches of urban scholarship, even if these literature strands did not always operate under the same paradigmatic umbrella. Nonetheless, the usage of the term of shrinkage itself has become widespread only during the first decade of the century (Bernt 2016). Beyond its recent rise, the three most researched topics regarding shrinkage refer to: causes of shrinkage, trajectories or certain typologies of shrinkage, planning responses and strategies developed by the governing bodies (Haase et al. 2021). A fourth, unexpected topic in connection to shrinkage is that of urban regrowth. Urban regrowth has been a phenomenon studied recently, present especially in big cities (Kabisch, Haase, and Haase 2010), gathering increasingly more academic interest in the past few years.

The existing debates revolve around concepts such as reurbanization (Kabisch, Haase, and Haase 2010; Wolff et al. 2017) on the one hand, and extended urbanisation (Keil 2018) and post-suburbia (Charmes and Keil 2015), on the other hand. Reurbanization is of concern for urban scholars who study suburbanization as concomitant with urban shrinkage. For much of this literature, the urban life cycle model of van den Berg, Drewett and Klaassen (2013) supports the claim that these two tendencies are distinct sequences in a cyclic model of growth and decline. Another central aspect to reurbanisation is the problem of densification, which is seen as happening either in the urban core (Broitman and Koomen 2020) or in certain places within the city. However, in this framework, while temporarily simultaneous, suburbanisation and shrinkage are perceived as an opposing spatial trend: core shrinkage fades away as population returns in the core from suburbia (Kabisch, Haase, and Haase 2010). 
Extended urbanisation and post-suburbia are, on the other hand, key concepts in Roger Keil's analysis of contemporary urbanization (Charmes and Keil 2015; Keil, 2018). Post-suburbanism refers to the structural changes which alter the internal organisation of the suburbs. This is the outcome of the process of extended urbanisation which re-shapes the peripheries of the cities. Our paper follows this second corpus of literature, and we avoid a simple opposition between shrinking and growth and follow a more complex typology of urban dynamic. More specifically, we interpret the shrinkage of the urban cores as a process which pertains to extended urbanisation, without having some strong assumptions about urban life cycles.

In this paper, three hypotheses regarding the different trajectories of Romania's urban localities were tested. First, we hypothesise that post-shrinkage growth (core shrinkage and periurban growth) is mainly concentrated around the biggest urban growth poles of Romania, especially in their peri-urban area and the surrounding localities. Secondly, as the country experienced a period of economic expansion in the previous decade, in the aftermath of the 2008 Financial Crisis, we argue that cities with a growing manufacturing sector have experienced a period of relative growth. This is mainly concerned with the outsourcing of manufacturing and industrial capabilities in the Eastern side of the continent. Third, we expect that indexes regarding human development and economic structure would reveal important social inequalities both within the cities and between themselves.

\section{Data and definitions}

The typology presented in this article is primarily intended to connect several different dimensions that have been considered separately. In a broad sense, all categories employed here are used in documenting urban shrinkage. The original contribution of this paper is to create a classification that considers the various bodies of knowledge and draws connections between them. After all, it is important to delineate various existing trajectories and understand the unique shrinking identity of Romanian cities. Therefore, existing indicators reflect a wide range of topics in shrinkage research, including demographics, economics, human development, governance of shrinkage, and environmental issues. The exact list of indexes can be found in Table 1 .

The demographic dimension was, perhaps, the most documented across the existing literature (Bernt 2016; Haase et al. 2014). Population loss was the main concern, being marked as one of the distinctive features of shrinkage, and different explanations were attributed to this phenomenon (Martinez-Fernandez, 
$\mathrm{Wu}$, et al. 2012b). We have used three types of demographical indexes: the percentual change of the population volume, the newly born and the number of children. The children dependency rate captures whether the city has an increasing population of children compared with adults, a specific trait for the peri-urban cities and of the growing cities.

Economic structure is another influential aspect, as population loss was interpreted as being either correlated or caused by economic decline. Moreover, the process of shrinkage was intensely studied with a reference to deindustrialization, the best examples are those of mining cities (MartinezFernandez, Wu, et al. 2012). Another important feature within the shrinkage literature was that of the transition from industrial, labour intensive regimes to newer forms which require technology and less work force. To capture the economic specialisation of the cities, we computed the percentage of the labour force by sector, based on firm level data. The share of labour force employed in agriculture, industry, and commercial services was computed at city level based on employees across all the locations of the companies in Romania. We have used in the analysis just the commercial services and not the whole services sector, to introduce in the analysis, the more dynamic outsourced services.

To capture the difference between social transformations of the city given the city's position in the national and continental networks of supply in manufacturing, services, or agriculture, we have used three types of indexes. The first one is the percentage of workforce with tertiary education, either post high school or university diploma. This type of information is available at locality level only for 2011, the year of the census. The baccalaureate promotion rate is used in the analysis to capture the educational stock of a city. The decision is based on the observation that the academic achievements of upper secondary students in national standardised tests at city level are the result of the social composition of their classes as well as of the distribution of human resources among schools (Hatos 2010). The Local Human Development Index (ILHDI), put forward by Sandu (2020), is an adaptation of The Inequalityadjusted Human Development Index (IHDI) proposed by Sen (2001). The ILHDI has three dimensions: human capital (approximated by internet connection index to 100 inhabitants), health capital (standardised rate of mortality) and material capital (average size of household area/dwelling, gas consumption per inhabitant, and taxes collected on turnover).

Governance is another point of concern in the literature debating shrinkage. Although a more recent focus, its importance is raised due to European research projects aimed at studying and understanding the process of how different cities adapt and plan their strategies to cope with shrinkage (Pallagst et al. 2021). We have used two different analytical categories: city 
income and expenditure and the measure of e-governance (Urs, 2021). The income of a locality is strongly linked with the volume of its workforce, its income and disposable income. Based on the city's turnover we have generated three indexes: the gross local income for 2019, the local taxes from personal income, and the share of property taxes from the total city income.

Descriptive statistics: item used in analysis

Table 1.

\begin{tabular}{|c|c|c|c|c|c|c|}
\hline $\begin{array}{l}\text { Principal } \\
\text { component }\end{array}$ & Item & Mean & $\begin{array}{l}\text { Std. } \\
\text { Dev }\end{array}$ & Min & Max & Source \\
\hline \multirow[t]{5}{*}{$\begin{array}{l}\text { Growing } \\
\text { cities }\end{array}$} & $\begin{array}{l}\text { New floor space in the } \\
\text { urban area } \\
2009-2019\end{array}$ & 0.408 & 0.126 & -0.028 & 0.899 & $\begin{array}{l}\text { NIS LOC103B } \\
(2021)\end{array}$ \\
\hline & $\begin{array}{l}\text { Percent change of Popu- } \\
\text { lation in the urban area } \\
2009-2019\end{array}$ & -0.032 & 0.137 & -0.170 & 1.502 & $\begin{array}{l}\text { NIS POP107D } \\
(2021) \\
\text { NIS POP310E } \\
(2021)\end{array}$ \\
\hline & $\begin{array}{l}\text { New floor space in the } \\
\text { urban area } \\
1990-2008\end{array}$ & 0.318 & 0.225 & -0.007 & 1.547 & $\begin{array}{l}\text { NIS LOC103B } \\
(2021)\end{array}$ \\
\hline & $\begin{array}{l}\text { Businesses per } 1000 \text { in- } \\
\text { habitants, } 2018\end{array}$ & 22 & 12 & 3.740 & 94 & $\begin{array}{l}\text { NIS COMP } \\
(2021)\end{array}$ \\
\hline & $\begin{array}{l}\text { Share of peri-urban turn- } \\
\text { over, } 2018\end{array}$ & 0.402 & 0.291 & 0.013 & 0.990 & $\begin{array}{l}\text { NIS COMP } \\
(2021)\end{array}$ \\
\hline \multirow[t]{3}{*}{$\begin{array}{l}\text { Service } \\
\text { Leaning }\end{array}$} & $\begin{array}{l}\text { Average annual capital } \\
\text { expenditures per capita } \\
\text { (including EU funds) for } \\
\text { 2008-2018 }\end{array}$ & 92 & 71 & 15 & 564 & $\begin{array}{l}\text { MPWDA } \\
(2021)\end{array}$ \\
\hline & $\begin{array}{l}\text { Share of expenditures for } \\
\text { staff salaries (average for } \\
\text { 2008-2018) }\end{array}$ & 0.436 & 0.107 & 0.025 & 0.821 & $\begin{array}{l}\text { MPWDA } \\
(2021)\end{array}$ \\
\hline & $\begin{array}{l}\text { Share of employees in } \\
\text { commercial services } \\
2018\end{array}$ & 0.041 & 0.057 & 0.000 & 0.434 & $\begin{array}{l}\text { NIS COMP } \\
(2021)\end{array}$ \\
\hline $\begin{array}{l}\text { Liveable } \\
\text { cities }\end{array}$ & $\begin{array}{l}\text { Attainment rate of the } \\
\text { secondary school di- } \\
\text { ploma, } 2018\end{array}$ & 0.562 & 0.238 & 0.000 & 1.000 & $\begin{array}{l}\text { MNE } \\
(2018)\end{array}$ \\
\hline
\end{tabular}




\begin{tabular}{|c|c|c|c|c|c|c|}
\hline $\begin{array}{l}\text { Principal } \\
\text { component }\end{array}$ & Item & Mean & $\begin{array}{l}\text { Std. } \\
\text { Dev }\end{array}$ & Min & Max & Source \\
\hline & $\begin{array}{l}\text { Children dependency } \\
\text { rate } 2018\end{array}$ & 0.225 & 0.047 & 0.121 & 0.509 & $\begin{array}{l}\text { NIS POP107D } \\
(2021)\end{array}$ \\
\hline & $\begin{array}{l}\text { Local human develop- } \\
\text { ment index } 2018\end{array}$ & 60 & 9 & 25 & 96 & $\begin{array}{l}\text { Sandu } \\
(2020)\end{array}$ \\
\hline & $\begin{array}{l}\text { E-governance index } \\
2020\end{array}$ & 39 & 16 & 0 & 92 & $\begin{array}{l}\text { Urs } \\
(2021)\end{array}$ \\
\hline & $\begin{array}{l}\text { Share of local taxes in } \\
\text { City's Hall revenues, } \\
2019\end{array}$ & 0.147 & 0.069 & 0.002 & 0.675 & $\begin{array}{l}\text { MPWDA } \\
(2021)\end{array}$ \\
\hline & $\begin{array}{l}\text { Share of population less } \\
\text { than } 5 \text { minutes away } \\
\text { from a public transport } \\
\text { station }(2020)\end{array}$ & 0.349 & 0.216 & 0.000 & 0.884 & $\begin{array}{l}\text { Pascu } \\
(2020 \mathrm{~b})\end{array}$ \\
\hline \multirow[t]{3}{*}{$\begin{array}{l}\text { Industrial } \\
\text { Leaning }\end{array}$} & $\begin{array}{l}\text { Share of employees in in- } \\
\text { dustry, } 2018\end{array}$ & 0.131 & 0.167 & 0.000 & 2.151 & $\begin{array}{l}\text { NIS COMP } \\
(2021)\end{array}$ \\
\hline & Gross local income, 2018 & 90,80 & 11,247 & 376 & 12,8327 & $\begin{array}{l}\text { MPWDA } \\
\text { (2021) }\end{array}$ \\
\hline & $\begin{array}{l}\text { Average personal income } \\
\text { tax per capita for } 2008 \text { - } \\
2018\end{array}$ & 191 & 114 & 0 & 1356 & $\begin{array}{l}\text { MPWDA } \\
(2021)\end{array}$ \\
\hline \multirow[t]{4}{*}{$\begin{array}{l}\text { Sprawling } \\
\text { cities }\end{array}$} & $\begin{array}{l}\text { Workforce with high- } \\
\text { school, post-high-school, } \\
\text { or university diploma } \\
\text { (2018) }\end{array}$ & 0.257 & 0.097 & 0.062 & 0.517 & $\begin{array}{l}\text { Census, } \\
2011\end{array}$ \\
\hline & $\begin{array}{l}\text { Number of citizens for } \\
\text { each city hall employee } \\
\text { in } 2018\end{array}$ & 354 & 169 & 45 & 1296 & NACS (2018) \\
\hline & $\begin{array}{l}\text { Share of newly born in } \\
\text { the peri-urban areas } \\
2019\end{array}$ & 0.559 & 0.208 & 0.110 & 0.981 & $\begin{array}{l}\text { NIS POP201D } \\
(2021)\end{array}$ \\
\hline & $\begin{array}{l}\text { Population changes in } \\
\text { the peri-urban area } \\
2009-2019\end{array}$ & 0.000 & 0.133 & -0.190 & 0.986 & $\begin{array}{l}\text { NIS POP107D } \\
(2021) \\
\text { NIS POP310E } \\
(2021)\end{array}$ \\
\hline
\end{tabular}


A TYPOLOGY OF SHRINKING CITIES:

THE SOCIAL AND ECONOMIC DYNAMIC OF ROMANIAN URBAN NETWORK 2010-2020

\begin{tabular}{|c|c|c|c|c|c|c|}
\hline $\begin{array}{l}\text { Principal } \\
\text { component }\end{array}$ & Item & Mean & $\begin{array}{l}\text { Std. } \\
\text { Dev }\end{array}$ & Min & Max & Source \\
\hline & $\begin{array}{l}\text { New floor space change } \\
\text { in the peri-urban area } \\
2009-2019\end{array}$ & 0.315 & 0.220 & -0.071 & 1.699 & $\begin{array}{l}\text { NIS LOC103B } \\
(2021)\end{array}$ \\
\hline \multirow[t]{3}{*}{$\begin{array}{l}\text { Green } \\
\text { cities }\end{array}$} & $\begin{array}{l}\text { Air quality index } \\
\text { (100 good, } 1 \text { bad })\end{array}$ & $\begin{array}{c}61.46 \\
7\end{array}$ & 7.151 & 31 & 77 & $\begin{array}{l}\text { Ioja } \\
(2020)\end{array}$ \\
\hline & $\begin{array}{l}\text { Green spaces per capita } \\
\text { (sqm) }\end{array}$ & 25 & 44 & 0.724 & 677 & $\begin{array}{l}\text { Pascu } \\
\text { (2020a) }\end{array}$ \\
\hline & $\begin{array}{l}\text { Share of employees agri- } \\
\text { culture } 2018\end{array}$ & 0.009 & 0.011 & 0.000 & 0.087 & $\begin{array}{l}\text { NIS COMP } \\
(2021)\end{array}$ \\
\hline
\end{tabular}

Data source: authors' calculations.

The index of e-governance is a complex measure developed by Urs (2021) that quantifies five dimensions of engagement on behalf of the public administration with its citizens: (1) citizen participation and active engagement (participatory budgeting, newsletters, online audiences, surveys, social media, online debates, etc.), (2) online services (taxes, fines payment, online registration, online notifications and complaints, etc.), (3) the quality and volume of the information on the Mayor's Office webpage, (4) the design of the webpage, and (5) the security of the personal data.

The existing body of research points to the importance of environmental issues in the process of shrinkage but it rather refers to shock-events such as natural disasters. The aim of our typology is to stress the importance of environmental factors in developing a particular trajectory starting from indexes which facilitate creating a hierarchy among cities from this perspective. These indexes are the specific air quality index and the available green spaces per capita at city level. The Specific Air Quality Index (AQI) is an index constructed by Ioja (2020) and is determined based on the values of six indicators: particulate matter (PM10), ozone (03), lead (Pb), carbon monoxide (CO), sulphur dioxide (SO2), carbon dioxide nitrogen (NO2). The noxious substances were reported at the maximum permitted concentration and were classified into four categories: very dangerous, dangerous, moderately dangerous, and not very dangerous. The index is the arithmetic mean of all monitored toxins. Green spaces per capita is an index developed by Pascu (2020a) and quantifies the natural areas with recreational potential. Even though there is a strong geographical effect in terms of natural areas in peri-urban areas, there are green spaces with recreational potential that cities can capitalise on to increase accessibility to quality green space. 


\section{Model specification}

First, we summarise the datasets using principal component analysis, a method that reduces a large set of attributes to a smaller, more manageable one, synthesising the variability of the initial set into its principal axes of variation (Shlens 2014). The method depicts a clearer image of the initial complex spatial distribution reducing the relations between these variables to only six indexes without losing much information. To increase the interpretability of the data we used an oblimin rotation (see Table 4) to summarise the common variation (Clarkson and Jennrich 1988). The reduced data are related to the income of the workforce, the sectorial structure of the labour force, its wellbeing (public spending, residential space, green space, air quality) and data that quantifies the demographical composition (natural growth, age structure, volume change, human capital, and human development). The initial distribution of the 25 variables introduced in the analysis were highly skewed, given the very nature of the urban network. All the principal components are standardised variables, yet, they do not have a normal distribution. We did not perform any normalisation on the principal components, or the initial values, since that decision would have had important classification effects: cities that are quite different would have been grouped in the same cluster. We preferred to group the cities that are over-performing or underperforming on a component and have a container cluster with all the cities that score close enough to average on all components.

Second, we classify Romanian cities using a k-means algorithm (Hartigan and Wong 1979) based on the six principal components that summarised the initial set of data in the previous step. We obtained a classification of Romanian cities in seven classes. We have optimised the algorithm, by forcing it to form six clusters that uniquely capture each principal component, by providing initial starting seeds for the formation of the clusters. Since the principal components are standardised, the initial values were 1.98, that is the threshold for a significant departure from the value of $95 \%$ of the cases in a two tailed normal distribution. A seventh cluster was formed, which contained one third of the cities analysed and were scoring as average on all principal components - that is, they were around the null value.

Third, to further unpack the structure of the groups we drill down the classification for some of the clusters that had a bigger number of cases. At this step we also used variables aggregated at locality level to create clusters within the groups obtained at the previous step. However, this time the focus shifted to the sectorial structure of the capitals and the return on workforce for capital (the turnover per employee, the percentual change in employees between 2011 
and 2018 and the share of employed from the working). These analyses used the same k-means algorithms (Hartigan and Wong 1979). To make the subgroups comparable we provide descriptive statistics for the drill down variables also at the level of the groups.

\section{Results}

\section{Principal Components Analysis: multiple dimension of variations}

Based on the common correlation between the 25 variables that capture the social composition at locality level in the last decade in Romania, the principal component algorithm identified six patterns (see Table 2 and Table 3). The names of the six patterns were chosen by the authors to compactly capture the sets of variables that correlate with each other. The analysis summarises $71,4 \%$ of the total variance of the variables. All indexes have high internal consistency, with a McDonald's $\omega$ greater than 0.850 , with two notable exceptions: liveable cities and green cities. The reason for liveable cities dimension rests on the fact that the component captures the local state capacity, a highly contingent factor on local political configurations. The green cities component captures three highly structured spatial distributions, but which are coincidentally linked together as explained bellow. Despite the lower internal validity, we opted to use these measures since they responded to theoretical expectations.

Table 2.

Principal Components Analysis: profile variables and their constituent items

\begin{tabular}{llcc}
\hline $\begin{array}{l}\text { Principal } \\
\text { component }\end{array}$ & Item & Loading & Communality \\
\hline $\begin{array}{l}\text { Growing } \\
\text { cities }\end{array}$ & New Floor Space in the Urban Area 2009-2019 & 0.827 & 0.300 \\
& $\quad$ Population Change in the Urban Area 2009-2019 & 0.808 & 0.333 \\
& $\quad \begin{array}{l}\text { Share of New Floor Space developed after 1990 } \\
\text { in 2018 }\end{array}$ & 0.796 & 0.338 \\
& Number of businesses per 1000 inhabitants & 0.470 & 0.225 \\
& $\begin{array}{l}\text { Share of Peri-urban Private Companies Revenue } \\
\text { in 2018 }\end{array}$ & 0.460 & 0.292 \\
\hline $\begin{array}{l}\text { Service } \\
\text { Leaning }\end{array}$ & $\begin{array}{l}\text { Average Annual Capital Expenditures per Capita } \\
\text { (including EU Funds) for 2008-2018 }\end{array}$ & 0.841 & 0.286 \\
\hline
\end{tabular}




\begin{tabular}{|c|c|c|c|}
\hline $\begin{array}{l}\text { Principal } \\
\text { component }\end{array}$ & Item & Loading & Communality \\
\hline & $\begin{array}{l}\text { Share of Expenditures for Staff Salaries (average } \\
\text { for 2008-2018) }\end{array}$ & -0.679 & 0.283 \\
\hline & Share of Employees in Commercial Services 2018 & 0.476 & 0.253 \\
\hline \multirow[t]{6}{*}{ Liveable city } & $\begin{array}{l}\text { Attainment rate of the secondary school diploma } \\
\text { in } 2018\end{array}$ & -0.567 & 0.454 \\
\hline & Children Dependency Rate 2018 & 0.701 & 0.394 \\
\hline & Local Human Development Index 2018 & -0.541 & 0.202 \\
\hline & e-Governance Index 2020 & -0.496 & 0.537 \\
\hline & Share of Revenues from Local Taxes in 2019 & -0.485 & 0.503 \\
\hline & $\begin{array}{l}\text { Share of Population Less than } 5 \text { minutes away } \\
\text { from a Public Transport Station (2020) }\end{array}$ & -0.489 & 0.431 \\
\hline \multirow{3}{*}{$\begin{array}{l}\text { Industrial } \\
\text { Leaning }\end{array}$} & Share of Employees in Industry 2018 & 0.925 & 0.197 \\
\hline & Gross Local Income 2018 & 0.852 & 0.195 \\
\hline & $\begin{array}{l}\text { Average Personal Income Tax per Capita for } \\
\text { 2008-2018 }\end{array}$ & 0.490 & 0.207 \\
\hline \multirow[t]{5}{*}{$\begin{array}{l}\text { Sprawling } \\
\text { city }\end{array}$} & $\begin{array}{l}\text { Workforce with high-school, post-high-school, or } \\
\text { university diploma (2018) }\end{array}$ & -0.838 & 0.313 \\
\hline & $\begin{array}{l}\text { Number of Citizens for each City Hall employee in } \\
2018\end{array}$ & -0.701 & 0.410 \\
\hline & $\begin{array}{l}\text { Share of newly born in the Peri-urban Areas } \\
2019\end{array}$ & 0.435 & 0.284 \\
\hline & $\begin{array}{l}\text { Population Change in the Peri-urban Area 2009- } \\
2019\end{array}$ & 0.621 & 0.198 \\
\hline & $\begin{array}{l}\text { New Floor Space Change in the Peri-urban Area } \\
2009-2019\end{array}$ & 0.593 & 0.232 \\
\hline \multirow[t]{3}{*}{ Green city } & Air Quality Index (100 good, 1 bad) & 0.764 & 0.388 \\
\hline & Green spaces per capita (sqm) & 0.490 & 0.663 \\
\hline & Share of Employees Agriculture 2018 & -0.508 & 0.623 \\
\hline
\end{tabular}

Data source: authors' calculations. 
The "growing locality" component: groups changes in population volume and newly constructed floor spaces in urban and peri-urban areas, with the location of the business in either urban or peri-urban areas number of business per capita and the share of companies' turnover in the peri-urban area as opposed to the urban core).

The "service leaning" component: personal income is bigger in the cities with a larger share of employees in commercial services. Also, public spending is focused more on capital expenditure and less on staff salaries. Many cities scoring on this principal component are peri-urban cities, in need of public investments, since the growth of the population puts pressure on the existing infrastructure, currently sized for a smaller city. This component is correlated with the "growing locality" component (see Table 4), suggesting that several growing localities are also service leaning.

Table 3.

Principal Components Analysis: validity measure for variance summarisation

\begin{tabular}{|c|c|c|c|c|c|c|c|}
\hline $\begin{array}{l}\text { Profile } \\
\text { variable }\end{array}$ & $\begin{array}{c}\text { Total } \\
\text { Eigen- } \\
\text { value }\end{array}$ & $\begin{array}{l}\text { Variance } \\
\text { explained }\end{array}$ & $\begin{array}{c}\text { McDonald's } \\
\omega\end{array}$ & $\begin{array}{l}\text { Total Vari- } \\
\text { ance } \\
\text { explained }\end{array}$ & KMO & $\chi^{2}(\mathbf{d f})$ & p. \\
\hline $\begin{array}{l}\text { Growing } \\
\text { cities }\end{array}$ & 6.834 & $29.7 \%$ & 0.908 & $71.40 \%$ & 0.814 & $\begin{array}{l}4512 \\
(300)\end{array}$ & $<0.001$ \\
\hline $\begin{array}{l}\text { Service } \\
\text { Leaning }\end{array}$ & 3.550 & $15.4 \%$ & 0.862 & & & & \\
\hline $\begin{array}{l}\text { Liveable } \\
\text { cities }\end{array}$ & 2.194 & $9.5 \%$ & 0.557 & & & & \\
\hline $\begin{array}{l}\text { Industrial } \\
\text { Leaning }\end{array}$ & 1.524 & $6.6 \%$ & 0.886 & & & & \\
\hline $\begin{array}{l}\text { Sprawling } \\
\text { cities }\end{array}$ & 1.266 & $5.5 \%$ & 0.874 & & & & \\
\hline $\begin{array}{l}\text { Green } \\
\text { cities }\end{array}$ & 1.090 & $4.7 \%$ & 0.650 & & & & \\
\hline
\end{tabular}

Data source: authors' calculations.

The "liveable cities" component: in the cities that score high on this component there are correlations between: (a) the human development index, (b) the attainment rate at the national standardised exam for the secondary 
school diploma, (c) the number of online services offered by city hall and used by the population, (d) the share of revenues derived from local taxes, more specifically from property taxes, (f) and the coverage of the public transportation system. We have treated this component as an index of how liveable a city is since it captures the human development and human capital. The correlations all have the negative sign, except for the children dependency rate which can pe interpreted, therefore, as an adult to children ratio.

Table 4.

Principal Components Analysis: correlation between components

\begin{tabular}{|c|c|c|c|c|c|c|}
\hline & $\mathbf{A}$ & B & $\mathbf{C}$ & D & $\mathbf{E}$ & $\mathbf{F}$ \\
\hline A Growing cities & 1.000 & & & & & \\
\hline B Service Leaning & 0.257 & 1.000 & & & & \\
\hline C Liveable Cities & -0.056 & -0.055 & 1.000 & & & \\
\hline $\begin{array}{l}\text { Industrial Lean- } \\
\text { ing }\end{array}$ & 0.145 & 0.102 & 0.238 & 1.000 & & \\
\hline E Sprawling Cities & -0.136 & 0.056 & 0.253 & -0.164 & 1.000 & \\
\hline F Green Cities & -0.097 & -0.002 & -0.011 & -0.135 & 0.045 & 1.000 \\
\hline
\end{tabular}

Data source: authors' calculations.

The "industrial leaning" component: the correlation pattern summaries the cities that have a higher percentage of employees in the industrial sector, generally located in the urban core, with higher personal incomes on average. The wages aggregated at local level tend to be larger, generating higher gross local income at city level. This correlation pattern captures the variation of the cities with employees in the industrial sector.

The "sprawling cities" component: a distinct correlation pattern, condensed in the fifth principal component, is that which summaries growth of the population and floor space in the peri-urban area after 2009, and the share of the employees with post-secondary education and in commercial services in the urban core. The cities that load high on this component have a bigger ratio of citizens to city hall employees, suggesting a larger city. In these cities the natality in the urban core is higher in absolute terms to the peri-urban core, since it has more inhabitants in the urban core compared to the peri-urban area; yet the population in the peri- 
urban area is growing at a faster pace compared to the population in the urban core. This component is correlated with the component that captures the liveability of the city (see Table 4).

The "green cities" correlation pattern: air quality correlates with green spaces per capita, and both are inversely correlated with the share of employees in agriculture. These correlation patterns emerge due to several contingent geographical distributions. The air quality index is highly correlated with meteorological conditions: the air pollutants circulate along the wind corridors (regional and continental) and are adversely related with heat (Di and Li 2019). In the case of Romania, the continental winds enter along the Danube from the western part of the country and circulate along the southern part converging in a whirl near the capital, where the air mass becomes stationary (Casado, Pastor, and Doblas-Reyes 2009). In the southern regions of Romania, Oltenia and Muntenia, the air quality index is the worst. In Bucharest, the air quality is simultaneously affected by wind stationarity and by the intense pollution generated by fossil fuel consumption of the city. Also, the continental winds that enter the Transylvanian Plateau, along the Someș and Mureș rivers, swirl in the basin formed by the Carpathian Mountains, becoming stationary in the middle of the Plateau (Casado, Pastor, and Doblas-Reyes 2009). These winds converge in the southern part of the Transylvanian Plateau creating another high point of polluted air. Therefore, a triangle of pollutants forms within the vertices represented by: Copșa Mica, Drobeta Turnu-Severin, and Bucharest (Ioja 2020). However, the intensive agriculture that engages paid workforce, especially for international grain production, is also in the southern part of Romania and the Transylvanian Plateau, forming a similar triangle. Therefore, the worst air in Romania inadvertently overlaps with its most richly employed agricultural areas. The two are also partially linked by mechanised agriculture's production of particulate matter which is a major air pollutant (Arslan and Aybek 2012). The third coincidence is in the distribution of agricultural land. In Romania, the distribution of natural areas with recreational potential overlaps with the mountain and sub-mountain geography. The plains and plateaus are largely occupied by agricultural land. Forests are organised in forestry administrations, and in terms of property they can be private, associative property or public. However, unlike agricultural land, most forests can be accessed by the public. Given this issue, Romania's south as well as its Transylvanian Plateau are best endowed with agricultural land cultivated by employees using mechanised tools, while the northern part of Romania has more recreational green spaces and forests. To sum up, air pollutants are less present where there are more green spaces and more present in areas with mechanised agriculture. Yet the link is not intrinsic to the three variables but is an effect of geographical contingencies. 


\section{Cluster Analysis: Groups of Cities}

To group the 319 cities in Romania we have used the Hartigan and Wong (1979) k-means algorithm based on the principal components that reduced the initial data set of variables that described the labour force. The principal component scores were generated based on a regression using the Anderson and Rubin (1949) algorithm. To select the number of groups we based our decision on the minimum Bayesian information criterion (Schwarz 1978; McNicholas 2016), which suggested seven classes. That was not surprising since we used six principal components as input data and the seventh cluster emerged as a container for all the values that averaged around the null value. The cluster analysis captures $52,7 \%$ of the variance of the initial components. This suggest that there are important variational aspects that our analysis must still address. The "liveable" and dispersed" components are negatively correlated with the other four components. Therefore, a negative value on the liveable component means a more liveable city, as well as a negative value on the dispersed component means a city with a bigger peri-urban area. The interpretation of the clusters is based on the mean of each principal component across the clusters.

We name cluster 1 as "Growth Poles". This category of cities groups the ones that score high on the sprawling" and liveable" components (both being negatively corelated with the rest of the components). On average, this group of cities (Brașov, Bucharest, Cluj-Napoca, Constanta, Craiova, Galați, Iași, Oradea, Pitești, Ploiești, Sibiu, Suceava, Timișoara) had a 32\% increase in peri-urban population and a $40 \%$ increase in floor space. On average, the urban core population contracted by $3 \%$, even if floor space in the core area expanded by $40 \%$ since 2009 and by $90 \%$ since 1990 . These cities have, on average, the biggest human development index, and the highest attainment rate of the secondary school diploma (the exam is called "baccalaureate", as in the French educational system). These cities are Romania's most populous, visible in the high average of citizens for each city hall employee and have some of the best public infrastructure networks, visible in the high degree of the population coverage by public transportation systems. The number of new-borns in the peri-urban area is the smallest compared with all the other groups of cities since the ratio of urban core population to the peri-urban area is the smallest. More precisely, the peri-urban population represents $20 \%$ of the total sum from the urban core and peri-urban area - the share being 32\% across Romania's urban network. Nonetheless, these are the cities that have expanded their urban footprint the most in the last 10 year, generating urban sprawl beyond their administrative boundaries. The gathering of cities in these clusters confirms the first hypothesis of a post-shrinking pattern that groups demographically shrinking cities that also have expanding peri-urban areas. 
Table 5.

Cluster of analysis: Goodness of fit statistics

\begin{tabular}{lcccccc}
\hline Sub-clusters & $\mathbf{R}^{2}$ & Silhouette & $\begin{array}{c}\text { Dunn } \\
\text { index }\end{array}$ & $\begin{array}{c}\text { Pear- } \\
\text { son's } \boldsymbol{\gamma}\end{array}$ & $\begin{array}{c}\text { En- } \\
\text { tropy }\end{array}$ & $\begin{array}{c}\text { Calinski- } \\
\text { Harabasz index }\end{array}$ \\
\hline $\begin{array}{l}\text { Industrial } \\
\text { cities }\end{array}$ & 0.527 & 0.190 & 0.036 & 0.398 & 1.609 & 57.929 \\
\hline
\end{tabular}

Table 6.

Cluster analysis: descriptive statistics and validation measures using analysis of variance

\begin{tabular}{|c|c|c|c|c|c|c|c|c|c|c|}
\hline \multirow{2}{*}{ Index } & \multicolumn{7}{|c|}{$\begin{array}{c}\text { Mean } \\
\text { (Standard deviation) }\end{array}$} & \multirow{2}{*}{$\begin{array}{c}F \\
(6 ; 312)\end{array}$} & \multirow{2}{*}{$\mathbf{P}$} & \multirow{2}{*}{$\eta^{2}$} \\
\hline & $\begin{array}{c}\text { Cluster } \\
1\end{array}$ & $\begin{array}{c}\text { Cluster } \\
2\end{array}$ & $\begin{array}{c}\text { Cluster } \\
3\end{array}$ & $\begin{array}{c}\text { Cluster } \\
4\end{array}$ & $\begin{array}{c}\text { Cluster } \\
5\end{array}$ & $\begin{array}{c}\text { Cluster } \\
6\end{array}$ & $\begin{array}{c}\text { Cluster } \\
7\end{array}$ & & & \\
\hline $\begin{array}{l}\text { Growing } \\
\text { locality }\end{array}$ & $\begin{array}{c}0.585 \\
(0.767)\end{array}$ & $\begin{array}{c}3.201 \\
(1.628)\end{array}$ & $\begin{array}{l}-0.116 \\
(0.547)\end{array}$ & $\begin{array}{l}-0.477 \\
(0.494)\end{array}$ & $\begin{array}{c}0.047 \\
(0.897)\end{array}$ & $\begin{array}{l}-0.265 \\
(0.486)\end{array}$ & $\begin{array}{c}0.283 \\
(0.593)\end{array}$ & 65.3 & $<0.001$ & 0.556 \\
\hline $\begin{array}{l}\text { Service } \\
\text { Leaning }\end{array}$ & $\begin{array}{c}0.102 \\
(0.937)\end{array}$ & $\begin{array}{c}1.597 \\
(1.389)\end{array}$ & $\begin{array}{l}-0.242 \\
(0.699)\end{array}$ & $\begin{array}{c}0.064 \\
(0.715)\end{array}$ & $\begin{array}{c}1.832 \\
(1.181)\end{array}$ & $\begin{array}{l}-0.401 \\
(0.676)\end{array}$ & $\begin{array}{l}-0.282 \\
(0.707)\end{array}$ & 41.2 & $<0.001$ & 0.442 \\
\hline $\begin{array}{l}\text { Liveable } \\
\text { cities }\end{array}$ & $\begin{array}{l}-1.224 \\
(0.599)\end{array}$ & $\begin{array}{l}-0.333 \\
(0.864)\end{array}$ & $\begin{array}{l}-0.739 \\
(0.753)\end{array}$ & $\begin{array}{c}0.302 \\
(0.682)\end{array}$ & $\begin{array}{l}-0.577 \\
(1.008)\end{array}$ & $\begin{array}{l}-0.262 \\
(0.558)\end{array}$ & $\begin{array}{l}1.500 \\
(0.7)\end{array}$ & 61.3 & $<0.001$ & 0.541 \\
\hline $\begin{array}{l}\text { Industrial } \\
\text { Leaning }\end{array}$ & $\begin{array}{c}0.559 \\
(0.452)\end{array}$ & $\begin{array}{l}0.311 \\
(0.97)\end{array}$ & $\begin{array}{c}1.381 \\
(1.526)\end{array}$ & $\begin{array}{l}-0.209 \\
(0.649)\end{array}$ & $\begin{array}{l}-0.397 \\
(0.511)\end{array}$ & $\begin{array}{l}-0.197 \\
(0.52)\end{array}$ & $\begin{array}{c}-0.686 \\
(0.419)\end{array}$ & 33.8 & $<0.001$ & 0.394 \\
\hline $\begin{array}{l}\text { Sprawl- } \\
\text { ing } \\
\text { cities }\end{array}$ & $\begin{array}{c}-3.55 \\
(1.897)\end{array}$ & $\begin{array}{c}-0.184 \\
(0.509)\end{array}$ & $\begin{array}{c}-0.356 \\
(0.768)\end{array}$ & $\begin{array}{c}0.450 \\
(0.342)\end{array}$ & $\begin{array}{l}0.420 \\
(0.36)\end{array}$ & $\begin{array}{c}0.160 \\
(0.559)\end{array}$ & $\begin{array}{l}0.128 \\
(0.45)\end{array}$ & 88.3 & $<0.001$ & 0.629 \\
\hline $\begin{array}{l}\text { Green } \\
\text { cities }\end{array}$ & $\begin{array}{c}-0.296 \\
(1.014)\end{array}$ & $\begin{array}{c}-0.662 \\
(0.956)\end{array}$ & $\begin{array}{c}-0.06 \\
(0.716)\end{array}$ & $\begin{array}{c}-0.871 \\
(0.821)\end{array}$ & $\begin{array}{c}0.900 \\
(1.722)\end{array}$ & $\begin{array}{c}0.544 \\
(0.559)\end{array}$ & $\begin{array}{c}0.260 \\
(0.617)\end{array}$ & 30.8 & $<0.001$ & 0.372 \\
\hline
\end{tabular}

Data source: authors' calculations. 
We name cluster 2 as "Periurban cities". This category of cities are the receivers of the sprawl pressures from the urban poles of larger cities. Fifteen cities have been classified as peri-urban cities, even though, in terms of geographical position there are 62 peri-urban cities. The difference comes from the specific quality of being a major buffer for the expansion of the urban pole from the nearby. Bucharest has created a huge stress on its neighbouring cities (Bragadiru, Buftea, Chitila, Năvodari, Otopeni, Ovidiu, Pantelimon, PopeștiLeordeni, Voluntari), but is not the only one. Brașov, Ploiești, Pitești, Constanta are surrounded by quite a large network of towns that grew both in population and in their urban footprint in the last decade. All the urban growth poles have generated sprawl in their periurban areas, yet many surrounding localities are communes. Most notable are Cluj-Napoca (with the spectacular population growth-burst of Floresti, Apahida and Baciu), Timissoara (with explosive growth of Dumbravița, Giroc and Moșnișa Nouă) and Iași (with the expansion of Valea Lupului, Miroslava and Rediu). Similar processes of peri-urban population growth by over $60 \%$ in the neighbouring communes happened near Brașov (Sânpetru) Craiova (Malu Mare and Carcea), Oradea (Paleu and Sântadrei) or Sibiu (Selimbăr). The peri-urban cities had on average a $36 \%$ boom in population and a $72 \%$ increase in floor space. The local human development index is the largest among all groups of cities, yet they have the lowest attainment rate for secondary school diplomas (36\%). This suggests that periurban cities are places of major social inequalities among households and are affected by a selective filtering of students: children of well-off parents are commuting to better schools. The peri-urban cities are not only a site of population growth but are also expansion sites for businesses. A particular case is Baia-Mare, a county capital with an industrial profile and not an urban growth pole, yet it neighbours an expanding peri-urban city Tăuții-Măgherăuș where most of the peri-urban growth of Baia Mare is absorbed.

We name cluster 3 as "Industrial Cities". This category of cities has experienced a contraction of the population in the urban core, on average by $4 \%$ and they have witnessed a moderate growth in population and business within their peri-urban area but have avoided urban sprawl. They host large companies, with high numbers of employees, generating a significant gross local income per capita at city level. On average, one third of employees are industrial workers (i.e. Alba Iulia, Arad, Baia Mare, Bistrița, Brăila, Buzău, Focșani, Miercurea Ciuc, Odorheiu Secuiesc, Piatra Neamț, Satu Mare, Târgu Mureș) and these cities have personal incomes per capita above the national level. Both the human development index and the attainment rate of secondary school diplomas are quite high. To sum up, this class of cities scores high on the industrial leaning and the liveability components simultaneously. Nonetheless, 
there are important variations in this class of cities in terms of size and rate of growth, hence a more detailed analysis is needed. This lends weight to the second hypothesis that the secondary cities have experienced economic growth as their industrial sector expended.

We name cluster 4 as "Agri-Cities" since they have a higher number of employees in agriculture compared with the national average. Nonetheless, the average percentage is quite small: $1,6 \%$. However, these cities have, on average, the worst air quality, and quite modest green spaces per capita. The component that we call "green" captures, as mentioned, a geographical correlation between three relatively independent variables: employment in agriculture, green areas in hectares and air quality. Still, it groups the cities that have large agricultural lands at their disposal. The specificity of highly mechanised agriculture is that it employs quite a small workforce. Most of these cities are found in the Romanian Plain in the South of the country and in the Transylvanian Plain, the area with the worst air in Romania. There are 78 cities grouped in this cluster and the internal variability of the cluster is quite large, suggesting the need to further differentiate within this group.

Figure 1.

Cluster analysis: spatial distribution of the seven cluster

Cluster 1: Growth poles; Cluster 2: Periurban cities; Cluster 3: Industrial Cities;

Cluster 4: Agri-Cities; Cluster 5: Tourist Cities; Cluster 6: the Catching-up Cities; Cluster 7: cities with internal labour reserves.

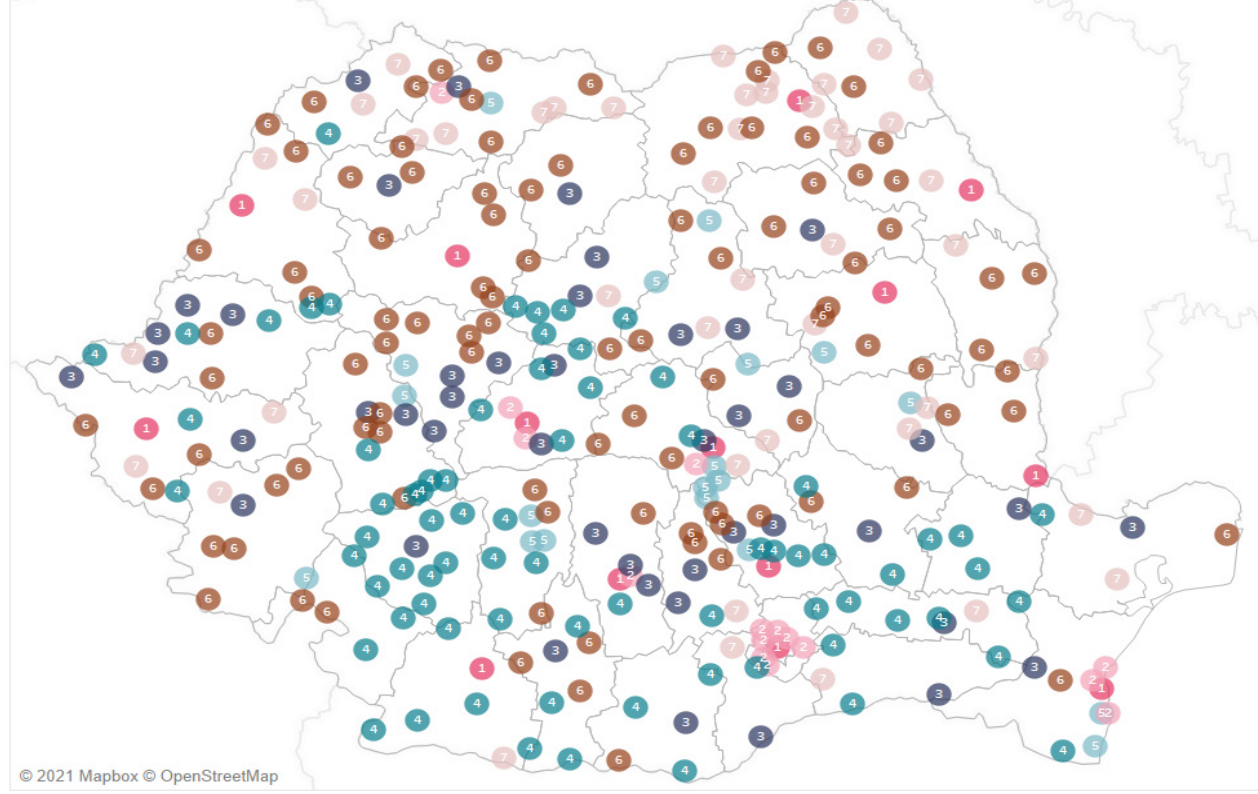

Data source: authors' calculations. 
We name cluster 5 as "Tourist Cities". They also score high on the "green" component, but they are the cities that have the best air quality and most green spaces per capita, on average. One in ten employees work in commercial services, and more specifically, in the hospitality industry. These are places with important social inequalities revealed by an above average human development index and a small attainment rate of secondary school diplomas. Many of these cities are surrounded by rural localities in their peri-urban area, which explains the higher peri-urban natality. Nonetheless, these cities were quite successful in attracting EU Funds and were able to invest the most in expanding their local infrastructure and amenities.

We name cluster 6 as the "Catching-up Cities". This is a generic catch all cluster; it groups cities that do not have any specific traits given our initial selection of variables driven by the interest to differentiate cities based on labour force composition. It groups 102 cities and, therefore, a more detailed analysis is needed to further describe these and to differentiate among them. This cluster confirms the third hypothesis that there are significant social and economic inequalities among the shrinking cities of Romania, given the major variation among them. Further analysis is necessary to capture this variability.

We name cluster 7 "Cities with Internal Labour Reserves" because they score, on average, low on the liveability index and industrial leaning components. The gross local income per capita is the smallest from all the clusters. These cities remain rather static in terms of population both in the urban core and the peri-urban area, yet the children dependency rate suggest a young population overall. These cities tend to be surrounded by rural peri-urban localities, that act as a continuous economic hinterland dominated by agrarian activities. There are rather few employees in the industrial sector and commercial services. There are 46 cities in this group and a finer grain drill down is needed to further describe this cluster. This cluster also confirms the third hypothesis suggesting that there are important inequalities among shrinking cities.

\section{Cluster Analysis: Subgroups of Cities}

In this section we describe the seven clusters based on variables that capture their economic sectorial structure and labour relations (waged or unwaged). We have used five variables: (1) the percentage of aggregate turnover in industry, (2) the percentage of aggregate turnover in services; (3) the average turnover per employee; (4) the percent change of employees at local level between 2011 and 2018; (5) the share of employees and employers out of employed in 2011. 
In addition, we further divide the clusters that have high within-group variations (industrial cities, agri-cities, catching-up cities, and cities with internal labour reserves) into the subgroups. For each of these groups we further applied a Hartigan and Wong (1979) k-means algorithm using the five variables mentioned above. Each variable was standardised using the mean and the standard deviation for the whole set of localities from Romania.

Table 7.

Cluster of analysis: goodness of fit statistics within the four cluster of cities further divided into subgroups

\begin{tabular}{lcccccc}
\hline Sub-clusters & $\mathbf{R}^{2}$ & Silhouette & $\begin{array}{c}\text { Dunn } \\
\text { index }\end{array}$ & $\begin{array}{c}\text { Pear- } \\
\text { son's } \boldsymbol{\gamma}\end{array}$ & $\begin{array}{c}\text { En- } \\
\text { tropy }\end{array}$ & $\begin{array}{c}\text { Calinski- } \\
\text { Harabasz index }\end{array}$ \\
\hline $\begin{array}{l}\text { Industrial cities } \\
\text { Agri-cities }\end{array}$ & 0.721 & 0.410 & 0.151 & 0.600 & 1.190 & 41.124 \\
\hline $\begin{array}{l}\text { Catching-up } \\
\text { cities }\end{array}$ & 0.379 & 0.180 & 0.093 & 0.443 & 0.955 & 26.300 \\
\hline $\begin{array}{l}\text { Cities with in- } \\
\text { ternal labour } \\
\text { reserves }\end{array}$ & 0.435 & 0.330 & 0.081 & 0.531 & 0.924 & 51.520 \\
\hline
\end{tabular}

Data source: authors' calculations.

The growth poles are cities that are specialised both in services (54\%) and industry (44\%). In these cities there is a rather small percentage of selfemployed and household workers, most of active age being employees or employers. The $16 \%$ increase in the number of employees stems from the expansion of the labour market. Productivity, as captured by the turnover per employees is high, the second among the cluster, after that of the peri-urban cities.

Peri-urban cities host several manufacturing and logistic facilities, which explains the higher percentage of turnover in the industrial sector (47\%) and a higher productivity given the capital inputs, as captured by the average turnover per employee. These localities are the dormitory towns of growth poles, which explains the astonishing employee increase of 38\%.

Industrial cities have the highest average turnover in industry among the seven clusters. The average is driven up by a sub-group of twenty-two cities that are even more specialised in industrial production. The rest of the twenty- 
four industrial cities have a similar distribution of capital across the sector as the urban growth poles. Moreover, these mixed industrial cities have a similar percentage of aggregate turnover in services as the growth poles. In fact, these mixed industrial cities have experienced quite a dynamic labour force, with an average increase of employees in a decade. All industrial cities have a small percentage of self-employed and working in the household, and a high percentage of employees and employers.

Table 8.

Assets by cluster: validation measures using analysis of variance

\begin{tabular}{|c|c|c|c|c|c|}
\hline Cluster & Index & df & $\mathbf{F}$ & $\mathbf{p}$ & $\eta^{2}$ \\
\hline \multirow[t]{5}{*}{$\begin{array}{l}\text { Industrial } \\
\text { cities }\end{array}$} & Turnover in industry, 2018 (\%) & $(1 ; 44)$ & 128.6 & $<0.001$ & 0.745 \\
\hline & Turnover in services, $2018(\%)$ & $(1 ; 44)$ & 122.3 & $<0.001$ & 0.736 \\
\hline & Turnover per employee 2018 & $(1 ; 44)$ & 0.5 & 0.500 & 0.010 \\
\hline & $\begin{array}{l}\text { Percent change in employment } \\
\text { 2011-2018 }\end{array}$ & $(1 ; 44)$ & 1.0 & $<0.335$ & 0.021 \\
\hline & Employees out of employed, 2011 & $(1 ; 44)$ & 6.5 & 0.015 & 0.128 \\
\hline \multirow[t]{5}{*}{ Agri-cities } & Turnover in industry, 2018 (\%) & $(2 ; 73)$ & 65.7 & $<0.001$ & 0.643 \\
\hline & Turnover in services, $2018(\%)$ & $(2 ; 73)$ & 30.7 & $<0.001$ & 0.456 \\
\hline & Turnover per employee 2018 & $(2 ; 73)$ & 21.0 & $<0.001$ & 0.366 \\
\hline & $\begin{array}{l}\text { Percent change in employment 2011- } \\
2018\end{array}$ & $(2 ; 73)$ & 6.1 & 0.004 & 0.142 \\
\hline & Employees out of employed, 2011 & $(2 ; 73)$ & 3.7 & $<0.098$ & 0.098 \\
\hline $\begin{array}{l}\text { Catching- } \\
\text { up cities }\end{array}$ & Turnover in industry, $2018(\%)$ & $(2 ; 97)$ & 82.9 & $<0.001$ & 0.631 \\
\hline
\end{tabular}




\begin{tabular}{|c|c|c|c|c|c|}
\hline Cluster & Index & df & $\mathbf{F}$ & $\mathbf{p}$ & $\eta^{2}$ \\
\hline & Turnover in services, 2018 (\%) & $(2 ; 97)$ & 88.9 & $<0.001$ & 0.645 \\
\hline & Turnover per employee 2018 & $(2 ; 97)$ & 1.7 & 0.184 & 0.034 \\
\hline & $\begin{array}{l}\text { Percent change in employment 2011- } \\
2018\end{array}$ & $(2 ; 97)$ & 99.8 & $<0.001$ & 0.668 \\
\hline & Employees out of employed, 2011 & $(2 ; 97)$ & 2.3 & 0.109 & 0.045 \\
\hline \multirow{5}{*}{$\begin{array}{l}\text { Cities with } \\
\text { internal la- } \\
\text { bour re- } \\
\text { serves }\end{array}$} & Turnover in industry, 2018 (\%) & $(2 ; 44)$ & 16.5 & $<0.001$ & 0.428 \\
\hline & Turnover in services, 2018 (\%) & $(2 ; 44)$ & 0.3 & 0.714 & 0.015 \\
\hline & Turnover per employee 2018 & $(2 ; 44)$ & 0.8 & 0.471 & 0.034 \\
\hline & $\begin{array}{l}\text { Percent change in employment 2011- } \\
2018\end{array}$ & $(2 ; 44)$ & 1.7 & 0.240 & 0.063 \\
\hline & Employees out of employed, 2011 & $(2 ; 44)$ & 40.339 & $<0.001$ & 0.647 \\
\hline
\end{tabular}

Data source: authors' calculations.

Agri-cities are cities that have smaller turnover per employee ratio compared with the previous cities. The turnover per employee can be also read as an added value of the employees. This suggest that, on average, these cities are less intensive in capital. The cluster analysis suggests that this group of cities can be further subdivided into three. First, there is a significant divergent sub-group of ten cities that, on average, use less labour force input per capital. This sub-group of cities has a specific sectorial profile that combines agriculture ( $41 \%$ of the aggregate turnover) with services ( $45 \%$ the aggregate turnover). The entire cluster has a relatively small share of employees from workers, suggesting significant internal labour reserves. Second, there is a sub-group of agri-cities with industry, which had an increase of $12 \%$ in the number of employees and has a distinctive industrial profile (66\% of the aggregate turnover). Third, there is a sub-group specialised in services (shrinking agri-cities) and some agriculture (8\%), which experienced a contraction in employment. 
Figure 1.

Cluster analysis: spatial distribution of the seven cluster

Cluster 1: Growth poles; Cluster 2: Peri-urban cities; Cluster 3: Industrial Cities; cluster 4: Agri-Cities (3a. High-end Agri-city; 3b. Agri-city with industry;

3c. Shrinking agri-cities); Cluster 5: Tourist Cities; Cluster 6: Catching-up Cities (6a. Catching-up Industrial towns; 6b. Public services towns; 6c. Cities with expanding labour markets); Cluster 7: cities with internal labour reserves

(7a. Small scale farming cities; 7b. Moderately expanding towns; 7c. Self-Sufficient Homestead Cities).

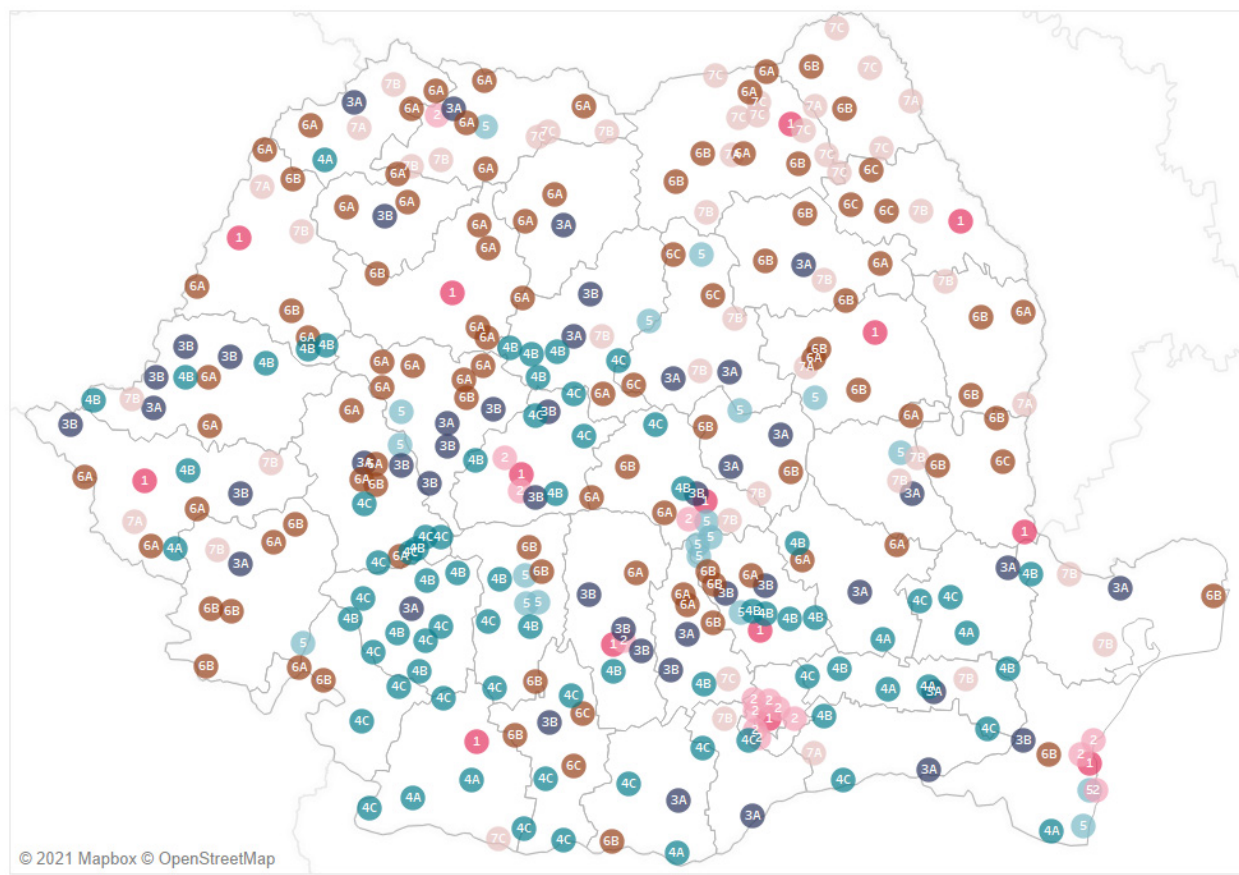

Data source: authors' calculations.

Tourist cities have a 55\% of the aggregate turnover in services, more specifically in hospitality with $91 \%$ of the working being employed. In addition, the local economy is stabilized by a working industry. 
Table 9.

Socio-economic groups and sub-groups of Romanian cities

\begin{tabular}{|c|c|c|c|c|c|c|c|}
\hline & \# & $\begin{array}{c}\text { Turnover } \\
\text { in agricul- } \\
\text { ture, } 2018\end{array}$ & $\begin{array}{l}\text { Turno- } \\
\text { ver in in- } \\
\text { dustry, } \\
2018\end{array}$ & $\begin{array}{l}\text { Turno- } \\
\text { ver in } \\
\text { services, } \\
2018\end{array}$ & $\begin{array}{c}\text { Turnover } \\
\text { per employ- } \\
\text { ees (euro), } \\
2018\end{array}$ & $\begin{array}{c}\text { Percent } \\
\text { change in } \\
\text { employ- } \\
\text { ment, } \\
\text { 2011-2019 }\end{array}$ & $\begin{array}{c}\text { Employ- } \\
\text { ees out } \\
\text { of em- } \\
\text { ployed, } \\
2011\end{array}$ \\
\hline $\begin{array}{l}\text { Urban Growth } \\
\text { Poles }\end{array}$ & 13 & $1 \%$ & $44 \%$ & $54 \%$ & 54,932 & $16 \%$ & $97 \%$ \\
\hline $\begin{array}{l}\text { Peri-urban } \\
\text { Cities }\end{array}$ & 15 & $1 \%$ & $47 \%$ & $52 \%$ & 57,254 & $38 \%$ & $96 \%$ \\
\hline $\begin{array}{l}\text { Industrial Cit- } \\
\text { ies }\end{array}$ & 46 & $2 \%$ & $61 \%$ & $37 \%$ & 48,717 & $19 \%$ & $95 \%$ \\
\hline $\begin{array}{l}\text { Mixed Indus- } \\
\text { trial Cities }\end{array}$ & 24 & $3 \%$ & $44 \%$ & $53 \%$ & 50,998 & $23 \%$ & $96 \%$ \\
\hline $\begin{array}{l}\text { Industrially } \\
\text { specialized Cit- } \\
\text { ies }\end{array}$ & 22 & $1 \%$ & $82 \%$ & $17 \%$ & 46,002 & $15 \%$ & $94 \%$ \\
\hline Agri-cities & 78 & $12 \%$ & $47 \%$ & $42 \%$ & 38,661 & $4 \%$ & $83 \%$ \\
\hline $\begin{array}{l}\text { High-end } \\
\text { Agri-city }\end{array}$ & 9 & $41 \%$ & $15 \%$ & $45 \%$ & 67,123 & $4 \%$ & $74 \%$ \\
\hline $\begin{array}{l}\text { Agri-city with } \\
\text { industry }\end{array}$ & 35 & $7 \%$ & $66 \%$ & $27 \%$ & 38,745 & $12 \%$ & $87 \%$ \\
\hline $\begin{array}{l}\text { Shrinking } \\
\text { agricities }\end{array}$ & 32 & $8 \%$ & $35 \%$ & $57 \%$ & 31,451 & $-5 \%$ & $82 \%$ \\
\hline Tourist Cities & 19 & $3 \%$ & $42 \%$ & $55 \%$ & 34,305 & $16 \%$ & $91 \%$ \\
\hline $\begin{array}{l}\text { Catching-up } \\
\text { Cities }\end{array}$ & 102 & $4 \%$ & $50 \%$ & $45 \%$ & 32,882 & $11 \%$ & $89 \%$ \\
\hline $\begin{array}{l}\text { Catching-up In- } \\
\text { dustrial towns }\end{array}$ & 52 & $3 \%$ & $64 \%$ & $33 \%$ & 34,448 & $5 \%$ & $89 \%$ \\
\hline $\begin{array}{l}\text { Public services } \\
\text { towns }\end{array}$ & 40 & $5 \%$ & $35 \%$ & $61 \%$ & 31,240 & $2 \%$ & $90 \%$ \\
\hline
\end{tabular}




\begin{tabular}{|c|c|c|c|c|c|c|c|}
\hline & \# & $\begin{array}{c}\text { Turnover } \\
\text { in agricul- } \\
\text { ture, } 2018\end{array}$ & $\begin{array}{c}\text { Turno- } \\
\text { ver in in- } \\
\text { dustry, } \\
2018\end{array}$ & $\begin{array}{l}\text { Turno- } \\
\text { ver in } \\
\text { services, } \\
2018\end{array}$ & $\begin{array}{c}\text { Turnover } \\
\text { per employ- } \\
\text { ees (euro), } \\
2018\end{array}$ & $\begin{array}{c}\text { Percent } \\
\text { change in } \\
\text { employ- } \\
\text { ment, } \\
\text { 2011-2019 }\end{array}$ & $\begin{array}{c}\text { Employ- } \\
\text { ees out } \\
\text { of em- } \\
\text { ployed, } \\
2011\end{array}$ \\
\hline $\begin{array}{l}\text { Cities with ex- } \\
\text { panding labour } \\
\text { markets }\end{array}$ & 10 & $6 \%$ & $41 \%$ & $53 \%$ & 30,955 & $79 \%$ & $83 \%$ \\
\hline $\begin{array}{l}\text { Cities with in- } \\
\text { ternal labour } \\
\text { reserves }\end{array}$ & 46 & $13 \%$ & $49 \%$ & $38 \%$ & 31,996 & $22 \%$ & $69 \%$ \\
\hline $\begin{array}{l}\text { Small scale } \\
\text { farming cities }\end{array}$ & 8 & $40 \%$ & $23 \%$ & $36 \%$ & 33,581 & $18 \%$ & $67 \%$ \\
\hline $\begin{array}{l}\text { Moderately ex- } \\
\text { panding towns }\end{array}$ & 23 & $8 \%$ & $55 \%$ & $36 \%$ & 30,651 & $30 \%$ & $83 \%$ \\
\hline $\begin{array}{l}\text { Self-Sufficient } \\
\text { Homestead Cit- } \\
\text { ies }\end{array}$ & 15 & $3 \%$ & $56 \%$ & $41 \%$ & 33,106 & $11 \%$ & $48 \%$ \\
\hline
\end{tabular}

Data source: authors' calculations.

Catching-up cities have a rather small turnover per employee, suggesting small sized companies. There are three distinctive sub-groups with relatively different profiles. A particular sub-group of cities had a spectacular $79 \%$ boost in employment, mostly in the industrial sector. Another group of 52 cities with a stable labour market are specialized in industrial production. A third group consists of forty cities specialized in services with a sizeable public sector and a small private sector.

The cities with internal labour reserves have an extremely low percentage of employees out of working. For some of these cities this is an opportunity for growth: for twenty-three cities, on average, employment expanded by $30 \%$ in the industrial sector. Given the small turnover per employee this suggests that the manufacturing sector is labour intensive. In a second sub-group of eight cities, in the agricultural sector the turnover grew by $40 \%$, in a similar vein as the high-end agri-cities. However, the major difference resides in the fact that the turnover per employee is rather low, suggesting that the farming activities are small scale. A third sub-group of fifteen cities have an extremely low share of employees out of working (48\%) and a just a tiny 3\% aggregate turnover in agriculture, indicating that many households are engaged in un-waged labour relations. 
A TYPOLOGY OF SHRINKING CITIES:

THE SOCIAL AND ECONOMIC DYNAMIC OF ROMANIAN URBAN NETWORK 2010-2020

\section{Conclusions}

The overall aim of this paper was to delineate the different trajectories of Romanian cities in the context of urban shrinkage. Far from being a unitary process, the outcome of this typology confirms the existence of distinct and highly localised shrinkage identities (Martinez-Fernandez, Audirac, et al. 2012). While shrinking has been originally seen as a linear phenomenon (for critiques of this perspective: Wolff \& Wiechmann, 2018), the present analysis points to overlapping trends. Moreover, by including cities which have a population of below fifty thousand inhabitants (which constitute the large majority in Romania), the picture gains more complexity and opens the way for further comparisons. Beyond the dominant representation of shrinkage as a process that is mainly correlated with population loss and economic decline, this paper calls for bridging together distinct dimensions which have been either understudied (such as the aspect of human development) or studied separately (such as governance of shrinkage and economic growth) across the existing literature. Therefore, the typology developed here accounts for understanding the process of shrinkage as a complex one, having a multitude of causes that determine peculiar trajectories (Martinez-Fernandez, Audirac, et al. 2012).

Our first hypothesis was that post-shrinkage growth (Wolff et al. 2017) affects the largest cities in Romania: while the urban core is contracting demographically, the suburbs are increasing and densifying. As it can be seen, several localities that have experienced growth are peri-urban settlements or towns situated around the main urban poles of the country. All Romanian cities cumulatively host 12.2 million inhabitants and their peri-urban areas another 5.8 million. The total number of inhabitants of the urban cores and peri-urban areas amass over eighteen million, which represents $81.4 \%$ of the total population of Romania. The urban growth poles are the most populous: together with their peri-urban areas they comprise $29 \%$ of the total population of Romania and $36 \%$ of urban dwellers. Following the extended urbanisation literature, we consider the inhabitants of the urban core and the peri-urban area as urban dwellers. All growth poles have expanded their peri-urban area, while, with a few exceptions (Alba Iulia, Bistrița, Cluj-Napoca, and Iași) the urban cores all experienced population contraction. This tendency, coupled with the diversification of economic structure and the change in built-up area, is manifest of the process of extended urbanisation and to the structural changes that it implies.

However, there are places which are not neighbouring the biggest urban settlements and have experienced growth. This is our second hypothesis, the cities with sizeable manufacturing sectors have experienced relative growth. And indeed, our expectation was confirmed. The second most populous 
cluster of localities includes the catching-up cities, that represents $23 \%$ of the total number of city dwellers. The third most populous category of cities are the industrial cities that make up of $18 \%$ the total population and $22 \%$ of urban dwellers. The economic growth can be attributed to direct foreign investments in sectors such as manufacturing or logistics, which have existed before at the locality's level. Therefore, here the problem of reurbanization needs to be addressed and studied further. That is, because the processes of urbanisation of secondary cities have a longer durée. The Romanian urban network developed after 1947, up until then $78 \%$ of the population was rural (Rotariu, Dumănescu, and Hărăguş 2017). The urban network was not really developed up to that point, however it had several strong regional capitals. Romania was formed by the union of several independent regions, at the end of the XIX century and the beginning of the XX century. These regions had strong cities with administrative functions and command and control roles in the export of semi-processed materials and raw materials (Ban 2020; Poenaru 2016; Verdery 1983). Banat region had the most sophisticated urban network and a complex integrated hinterland system. After 1960, the communist regime invested in the development of the urban network, tilting, by the end of the 1980s, the balance of the population towards the growing urban areas (Petrovici 2018). One specificity of socialist urbanisation across the region is the attention given to the densification of the urban network (Pobłocki 2018), which explains why the catching-up cities are the second most populous cluster and a gradual transformation of the agrilocalites in industrial localities. After World War II, the development of the urban network became a means of development across the national space. This type of policy has a specific modernist-functionalist background used to funnel the economic growth in the post-war era in Europe at large (Servillo, Atkinson, and Hamdouch 2017) and was partially changed by the policy of creating metropolitan areas (Fricke 2020), often criticised by the academic literature (Brenner 2004).

Our third hypothesis was that our social and economic factors reveal important social inequalities both within the cities and between themselves. In the beginning of the 2000s, the percentage of the urban population was a preaccession condition to become a member of the European Condition. Larger communes made of several villages were re-classified as cities. The transformation of rural communities in urban localities between 2002 and 2004, increased the number of towns with an agrarian profile. These towns are geographically clustered in the Southern plains, the Transylvanian Plain, and in the Moldavian region. These new agrarian cities are placed, given their natural endowment, in two different clusters: "the agri-cities" of the South and Centre and "the cities with internal labour reserves" of the North and East. Employment opportunities 
are rather scarce in these towns. Even if some of them are using more intensively capital resources, nonetheless the capital per employee is rather small compared with the cities from other clusters. Most of these cities have a very small service sector, effectively being only labour resources and not actual independent economic actors. The population loss in these cities (around 7\% since 2003) is even more dire than the general demographic contraction in Romania (around 4\% since 2003).

\section{REFERENCES}

Anderson, T. W. and H. Rubin. (1949). Estimation of the Parameters of a Single Equation in a Complete System of Stochastic Equations, Annals of Mathematical Statistics, 20.1: 46-63.

Arslan, S. and A. Aybek. (2012). Particulate Matter Exposure in Agriculture. In B. Haryanto (ed.) Air Pollution: A Comprehensive Perspective, pp. 73-104. Rijeka: InTech.

Audirac, I. (2018). Introduction: Shrinking Cities from Marginal to Mainstream: Views from North America and Europe. Cities 75: 1-5.

Ban, C. (2020). Organizing Economic Growth: Romania and Transylvania on the Eve of the Great War. Acta Musei Porolissensis 42.1: 16-30.

Bănică, A., M. Istrate, and I. Muntele. (2017). Challenges for the Resilience Capacity of Romanian Shrinking Cities. Sustainability, 9.12: 2289.

Berg, L. van den, R. Drewett and L. H. Klaassen. (2013). A Study of Growth and Decline : Urban Europe. Oxford: Pergamon Press.

Bernt, Matthias. 2016. The Limits of Shrinkage: Conceptual Pitfalls and Alternatives in the Discussion of Urban Population Loss. International Journal of Urban and Regional Research 40(2): 441-50.

Brenner, N. 2004. New State Spaces: Urban Governance and the Rescaling of Statehood. Oxford: Oxford University Press.

Broitman, D. and E. Koomen. (2019). The Attraction of Urban Cores: Densification in Dutch City Centres: Urban Studies 57.9: 1920-39.

Casado, M. J., M. A. Pastor, and F. J. Doblas-Reyes. (2009). Euro-Atlantic Circulation Types and Modes of Variability in Winter, In Theoretical and Applied Climatology, 96:17-29.

Charmes, E. and R. Keil. (2015). The Politics of Post-suburban Densification in Canada and France. Journal of Urban and Regional Research 39.3: 581-602

Clarkson, D. B. and R. I. Jennrich. (1988). Quartic Rotation Criteria and Algorithms. Psychometrika, 53.2: 251-259.

Constantinescu, I. P. (2012). Shrinking Cities in Romania: Former Mining Cities in Valea Jiului. Built Environment, 38.2: 214-28. 
Di, Y. H. and R. Li. (2019). Correlation Analysis of AQI Characteristics and Meteorological Conditions in Heating Season. In IOP Conference Series: Earth and Environmental Science, 242.2: 022067.

Eva, M., A. Cehan, and A. Lazăr. (2021). Patterns of Urban Shrinkage: A Systematic Analysis of Romanian Cities (1992-2020). Sustainability 2021, 13.13: 7514.

Fricke, C. (2020). European Dimension of Metropolitan Policies. Cham: Springer International Publishing.

Haase, Annegret, Dieter Rink, Katrin Grossmann, Matthias Bernt, Vlad Mykhnenko. (2014). Conceptualizing Urban Shrinkage., Environment and Planning A: Economy and Space 46.7: 1519-34.

Haase, A., M. Bernt, K. Großmann, V. Mykhnenko and D Rink. (2016). Varieties of Shrinkage in European Cities. European Urban and Regional Studies 23.1: 86-102.

Haase, A., M. Bontje, C. Couch, S. Marcinczak, D. Rink, P. Rumpele, M. Wolfff. (2021). Factors Driving the Regrowth of European Cities and the Role of Local and Contextual Impacts: A Contrasting Analysis of Regrowing and Shrinking Cities. Cities 108: 102942.

Hartigan, J. A., and M. A. Wong. (1979). Algorithm AS 136: A K-Means Clustering Algorithm. Journal of the Royal Statistical Society. Series C (Applied Statistics) 28.1: 108.

Hatos, Adrian. 2010. Multilevel Analysis of Academic Achievements of Upper Secondary Students in a Romanian City. Studia Universitatis Babes-Bolyai: Sociologia 55(1): 89-116.

Ianoș, I., I. Sîrodoev, G. Pascariu, and G. Henebry. 2016. Divergent Patterns of Built-up Urban Space Growth Following Post-Socialist Changes. Urban Studies 53.15: 317288.

Ioja, Cristian. 2020. Methodology for Pollution Monitoring in Romania. Bucharest: The World Bank.

Kabisch, N., D. Haase and A. Haase. 2010. Evolving Reurbanisation? Spatio-Temporal Dynamics as Exemplified by the East German City of Leipzig. Urban Studies 47.5: 967-90.

Keil, R.. 2018. Extended Urbanization, 'Disjunct Fragments' and Global Suburbanisms. Environment and Planning D: Society and Space 36(3): 494-511.

Lucheș, D., B. Nadolu and M. Dincă. 2011. The Patterns of Depopulation in Timişoara: Research Notes. Sociologie Românească 9.3: 76-89.

Martinez-Fernandez, C., Wu, C. T., Schatz, L. K., Taira, N., \& Vargas-Hernández, J. G. (2012). The shrinking mining city: urban dynamics and contested territory. International Journal of Urban and Regional Research, 36(2), 245-260

Martinez-Fernandez, C., I. Audirac, S. Fol and E. Cunningham-Sabot. 2012. Shrinking Cities: Urban Challenges of Globalization. International Journal of Urban and Regional Research, 36.2: 213-225.

McNicholas, P.D. (2016). Model-based clustering, Journal of Classification, 33.3: 331373.

MNE. 2018. Baccalaureate Results Session I and II. Bucharest: Ministry of National Education. 
A TYPOLOGY OF SHRINKING CITIES:

THE SOCIAL AND ECONOMIC DYNAMIC OF ROMANIAN URBAN NETWORK 2010-2020

MPWDA. (2021). Statement of Revenue and Expenditure of the Administrative-Territorial Units in the Period 1999-2019. Bucharest: Ministry of Public Works, Development and Administration.

Mykhnenko, V., and I. Turok. (2008). East European Cities: Patterns of Growth and Decline, 1960-2005. International Planning Studies 13.4: 311-42.

NACS. (2018). Number Employee in the Public Administration at Locality Level; Data on Demand. Bucharest: National Agency of Civil Servants.

NIS COMP. (2021). Companies on Headquarters and Work Points: NACE Code, Turnover and Employees; Data on Demand. Bucharest: National Institute of Statistics.

NIS LOC103B. (2021). The Living Area Existing at the End of the Year by Forms of Property, Counties, and Localities. Bucharest: National Institute of Statistics TEMPO Datasets.

NIS POP107D. (2021). Population by Domicile on 1st of January by Age Groups and Ages, Sexes, Counties, and Localities. Bucharest: National Institute of Statistics TEMPO Datasets.

NIS POP201D. (2021). Live Births by Counties and Localities. Bucharest: National Institute of Statistics TEMPO Datasets.

NIS POP310E. (2021). Definitive Immigrants by Counties and Destination Localities. Bucharest: National Institute of Statistics TEMPO Datasets.

Pallagst, K., R. Fleschurz, S. Nothof and T. Uemura. 2021. Shrinking Cities: Implications for Planning Cultures? Urban Studies 58.1: 164-81.

Pascu, I.-S. (2020a). Accessibility of green spaces at the locality level in Romania. Unpublished technical report, Bucharest: The World Bank.

Pascu, I.-S. (2020b). Accessibility of Public Transport at Local Level in Romania. Unpublished technical report. Bucarest: The World Bank.

Petrovici, N. (2018). Zona Urbană. O Economie Politică a Socialismului Românesc [The urban area. A Political Economy of Romanian Socialism]. Cluj-Napoca: Tact and Presa Universitară Clujeană.

Pobłocki, K. (2018). Retroactive Utopia: Class and the Urbanization of Self-Management in Poland. In J. Andrew, M. Baron, W. Kevin and W. David (eds.) The Routledge Handbook on Spaces of Urban Politics., pp. 375-88. New York and London: Routledge.

Poenaru, F. (2016). An Alternative Periodization of Romanian History. A Research Agenda. Studia Universitatis Babes-Bolyai: Sociologia 61.1: 129-46.

Popescu, C. (2014). Deindustrialization and Urban Shrinkage in Romania. What Lessons for the Spatial Policy? Transylvanian Review of Administrative Sciences 10.42: 181202.

Regional, M. B. (2016). The Limits of Shrinkage: Conceptual Pitfalls and Alternatives in the Discussion of Urban Population Loss. International Journal of Urban and Regional Research, 40.2: 441-50.

Rink, D., C. Couch, A. Haase, R. Krzysztofik, B. Nadolu and P. Rumpel. (2014). The Governance of Urban Shrinkage in Cities of Post-Socialist Europe: Policies, Strategies and Actors., Urban Research \& Practice, 7.3: 258-277. 
Rotariu, Traian, Luminiţa Dumănescu, and Mihaela Hărăguş. 2017. Demografia României în perioada postbelică (1948-2015) [The Demography of Romania in the Postwar Period (1948-2015)]. Iași: Polirom.

Sandu, D. (2020). Updating the Local Human Development Index: Algorithm and Applicability. Bucharest: The World Bank.

Schwarz, G. (1978). Estimating the Dimension of a Model. Annals of Statistics, 6: 461464.

Sen, A. (2001). Development as Freedom. Oxford: Oxford University Press.

Servillo, L., R. Atkinson, and A. Hamdouch. (2017). Small and Medium-Sized Towns in Europe: Conceptual, Methodological and Policy Issues. Tijdschrift voor Economische en Sociale Geografie 108.4: 365-79.

Shlens, J. (2014). A Tutorial on Principal Component Analysis. arXiv Machine Learning, 10404.1100.

Urs, N. (2021). FSPAC Local e-Government Services Assessment Index. Working Paper, Faculty of Political Sciences and Administrative Sciences, Cluj-Napoca: Babeș-Bolyai University.

Verdery, Katherine. (1983). Transylvanian Villagers. Three Centuries of Political, Economic, and Ethnic Change. Berkeley: University of California Press.

Wiechmann, T. and M. Wolff. (2013). Urban Shrinkage in a Spatial Perspective: Operationalization of Shrinking Cities in Europe 1990-2010. In The Congress of the Association of European Schools of Planning and the Association of Collegiate Schools of Planning, Dublin 15 July.

Wolff, M., A. Haase, D. Haase and N. Kabisch. 2017. The Impact of Urban Regrowth on the Built Environment. Urban Studies 54.12: 2683-2700.

Wolff, M. and T. Wiechmann. (2018). Urban Growth and Decline: Europe's Shrinking Cities in a Comparative Perspective 1990-2010. European Urban and Regional Studies 25.2: 122-39. 